\title{
Collaboration of Turkish Scholars: Local or Global?*
}

\author{
Umut Al \\ Umut Sezen \\ İrem Soydal \\ Zehra Taşkın \\ Güleda Düzyol
}

Umut Al

İrem Soydal

Zehra Taşkın

Güleda Düzyola

Hacettepe University

Department of Information

Management

06800 Beytepe, Ankara

Turkey

umutal@hacettepe.edu.tr soydal@hacettepe.edu.tr ztaskin@hacettepe.edu.tr gduzyol@hacettepe.edu.tr

\section{Umut Sezen}

Hacettepe University

Department of Electrical and

Electronics Engineering

06800 Beytepe, Ankara,

Turkey

u.sezen@ee.hacettepe.edu.tr
*This is a slightly revised version of the paper appeared in the conference proceedings CD-ROM (pp. 522-532).

Originally presented at the 7th International Conference on Webometrics, Informetrics and Scientometrics (WIS) and 12th COLLNET Meeting, September 20-23, 2011, Istanbul Bilgi University, Istanbul, Turkey.

Published Online First: 10 March 2012

http://www.tarupublications.com/journals/cjsim/cjsim.htm

(c) Taru Publications $\mathbb{P}$ 


\section{Introduction}

Scholarly collaboration can be simply defined as two or more researchers working together. Bozeman and Corley (2004)[8] review and explain the main reasons for scholarly collaboration as: accessing the expertise, equipment or resources one does not have, encouraging cross-fertilization across disciplines, improving the access to funds, obtaining prestige or visibility, learning tacit knowledge about a technique, pooling knowledge for tackling large and complex problems, enhancing productivity, educating a student, and so on. Whatever the reasons for collaboration, it is a known fact that multiple authorship is increasingly dominating the scholarly communication.

Globalization affects scientific world as well as politics or economics. Especially technological innovations (Internet, mobile phones, etc.) and the increasing opportunities for the mobility of researchers remove the boundaries among countries. This fortifies the concept of multiple authorship in scholarly communication. Multiple authorship can be defined not only as two or more people from the same institution working together, but this concept may also indicate the collaboration of two or more researchers living in different continents.

Various bibliometric studies answering the common questions that were related to scholarly collaboration such as "what is research collaboration?", "how much is a collaboration worth?", "when do researchers collaborate?" addressed in the literature (Katz \& Martin, 2007[18]; Katz \& Hicks, 1997[12]; Birnholtz, 2007[8]). In our study, we tried to answer the question: Do Turkish scholars collaborate intranationally or internationally? Our main goal is to identify the collaboration rate of Turkey's publications by year and to reveal detailed collaboration patterns. The findings of this study can be helpful for science policy makers.

\section{Multiple authorship}

Researchers usually focus on two basic points while setting the trends on multiple authorship concept. These are determining the possible differences between the number of single and multi-authored publications in years and determining the changes in the average number of authors per publication. These numbers may vary according to different fields, yet it is observed that multiple authorship is becoming dominant in scientific communication over the years.

It has been observed from the ratio of multiple authorship and the number of authors per publication that the most rapid changes are in the medicine field. Some studies that had been carried out by different researchers in different time periods showed that there has been a significant increase in the average number of authors per article in medical journals (Cronin, 2001[9]; Glynn, Kerin, \& Sweeney, 2010)[14]. In an evaluation study of the journal called British Journal of Medicine, it was found out that the average number of authors per article was raised from 3.9 to 4.5 between the years 1985-1995 (Drenth, 2001[11]). In another study, which evaluated the same journal, it was revealed that in 1975 the average number of authors per article was 3.2 (Drenth, 1998, p. 219[10]). Similarly, radiology journals were 
evaluated (Mussurakis, 1993[23]) and it was found out that in 1991, the average number of authors per article increased two-fold when compared to the numbers in 1966. Occasionally, some extreme examples of multiple authorship can also be observed. For example, an article that was published in 1993 in New England Journal of Medicine has 972 authors. In this article it was observed that the average number of words per author was two (Liu, 2003 , p. 890[21]). In the field of medicine, the cooperation between sub-areas has become increasingly imperative. Besides, large number of clinical researches are being conducted and many projects are carried out by professors with the help of their assistants. These can be counted as the main reasons of multiple authorship in the field of medicine (Bennett \& Taylor, 2003, p. 264[5]).

Other than medicine, multiple authorship tendency is rising in the fields such as sociology (Hunter \& Leahey, 2008[15]), psychology (Kliegl \& Bates, 2011[20]) and agriculture (Farahat, 20021[13]) over the years. It is impossible to list here all the disciplines which have the tendency of multiple authorship, yet it is likely to generalize that the multiple authorship tendency is intensively observed in medicine and health sciences, followed by the basic sciences, engineering and social sciences respectively. In arts and humanities, studies with single author are still more commonly observed.

Especially in the last 25-30 years, it is seen that the number of authors per publication is rising significantly. The main reason of this is, the large-scaled researches are being conducted and to be able to conclude these researches, some other contributors such as datacleaners, field researchers, research designers are needed. On the other hand, some other factors such as increased telecommunication facilities, co-operation between researchers and new opportunities for authors to produce more publications, also contribute the emergence of multiple authorship. Sometimes, non-"real authors" can be added to the authors list of an article, in such a case, the contributions of all the authors of a publication can also be questioned.

\section{Scholarly collaboration}

The scholarly collaboration has grown rapidly since the late 1960s (Bordons \& Gómez, 2000[7]). Many studies (Sonnenwald, 2007 [26]; Wagner \& Leydesdorff, 2005 [28]) examined the growth of international scholarly collaboration and tried to understand the patterns of it. It is observed in the literature that researchers investigate different dimensions of scholarly collaboration such as, different countries (Anuradha \& Urs, 2007 [3]; Kim, 2005 [19]; Perianes-Rodríguez et al., 2011 [24]), specific fields (Ma \& Guan, 2005[22]; Yan, Ding, \& Zhu, 2010[29]), and impact of the publications (Persson, Glänzel, \& Danell, 2004[25]; Sooryamoorthy, 2009[27]). There are also some studies that examined these dimensions together (Arunachalam, 2000[4]; Zhao \& Guan, 2011[30]). In these studies, bibliometricians concentrated on the scientists' collaboration motives, structure of collaboration networks, international or intranational cooperation levels.

Scholarly collaboration emerges from the structure of relationships between scientific actors. Nevertheless, the number of studies on intranational scholarly collaboration is 
fewer than the number of international collaboration researches. One of the first examples of intranational scholarly collaboration studies was conducted by Katz (1992)[18]. Katz's research reported the characteristics of intranational collaboration within the United Kingdom, Canada and Australia. Furthermore, the study revealed that collaborations most frequently occurred between geographically close partners.

\section{Method}

This study aims to investigate the collaboration patterns of the Turkish scholars' publications within the citation indexes and the following research questions were addressed:

- Is the multiple authorship prevalent in the Turkish publications?

- Does the collaboration rate change by year?

- What is the distribution of collaboration types (intranational/international) authored by Turkish scholars?

- Does the rate and type of collaboration differ across the disciplines?

- Which countries are the most important collaborative partners of Turkish scholars?

The Thomson Reuters' Web of Science (WoS), was used to identify Turkish scholars' publications. WoS covers five different databases, namely, Science Citation Index, Social Sciences Citation Index, Arts $\mathcal{E}$ Humanities Citation Index, Conference Proceedings Citation Index (Science), Conference Proceedings Citation Index (Social Science \& Humanities). However Conference Proceedings Citation Index (Science) and Conference Proceedings Citation Index (Social Science $\mathcal{E}$ Humanities) are excluded in our study, and the term "publication" is defined, unless otherwise indicated, as journal articles, meeting abstracts, notes, and etc. which were authored by the scholars affiliated with Turkish institutions and included in the citation indexes. To identify the publications within these databases, an online search was performed on March 10, 2011, by using the "address" field. To obtain reliable data, different forms of Turkish addresses in different languages (e.g., "Turkey," “Turkiye”, "Turkei," "Turquie") were entered in the address field. After the data cleaning process, a total of 198,687 publications were identified. In this study we excluded the publications, which were published before 1970, since the total number (92) is too small to make analysis by year. Thus, our data set decreased to 198,595 records. Each record provided information about the author name(s), author address(es), publication year, language, document type, number of references included in the publication, and the number of citations that the publication received as of March 10, 2011. Separate files were created for publication years, subject categories, and author addresses for all of the 198,595 publications. The affiliation addresses of the first authors and joint authors were counted separately, and the countries were credited accordingly. 


\section{Findings}

As mentioned earlier, there were 198,595 publications that were indexed within the citation indexes between the years 1970-2009. The data represented in Figure 1 covers a 40 years period, however $80 \%$ of these publications belong to the year 2000 and onwards. In a previously conducted study (Al, 2008[1]) which was covering a 33 years period in Science Citation Index, it was mentioned that half of these publications were belong to the years 2001-2004. In our research, a similar trend was emerged. The number of publications that were produced by Turkey between the years 2005-2009 (106,232 publications) is greater than the remaining 35 years (1970-2004) of publication productivity (92,363 publications).

The number of authors was analyzed to identify the collaboration patterns in our study. The great majority $(88 \%)$ of publications had multiple authorship $(174,145)$. Figure 2 shows the gradual increase of multiple authorship rate in 10-year periods. Multiple authorship has reached to a top rate of $89 \%$ within the last ten years. Examining the last ten years data closer, it is seen that the ratio of multiple authorship for all the publications was not less than $88 \%$ in each and every year (Table 1 ).

A significant trend is clearly observed for the number of authors per publication over the years (Figure 3). It is seen that the average number of authors per publication was less than two during 1970-1972 time period, whereas it increased to over three in 1991. In the last six years (2004-2009) -which are included within the scope of our study-it is observed that the average number of authors per publication did not drop below four.

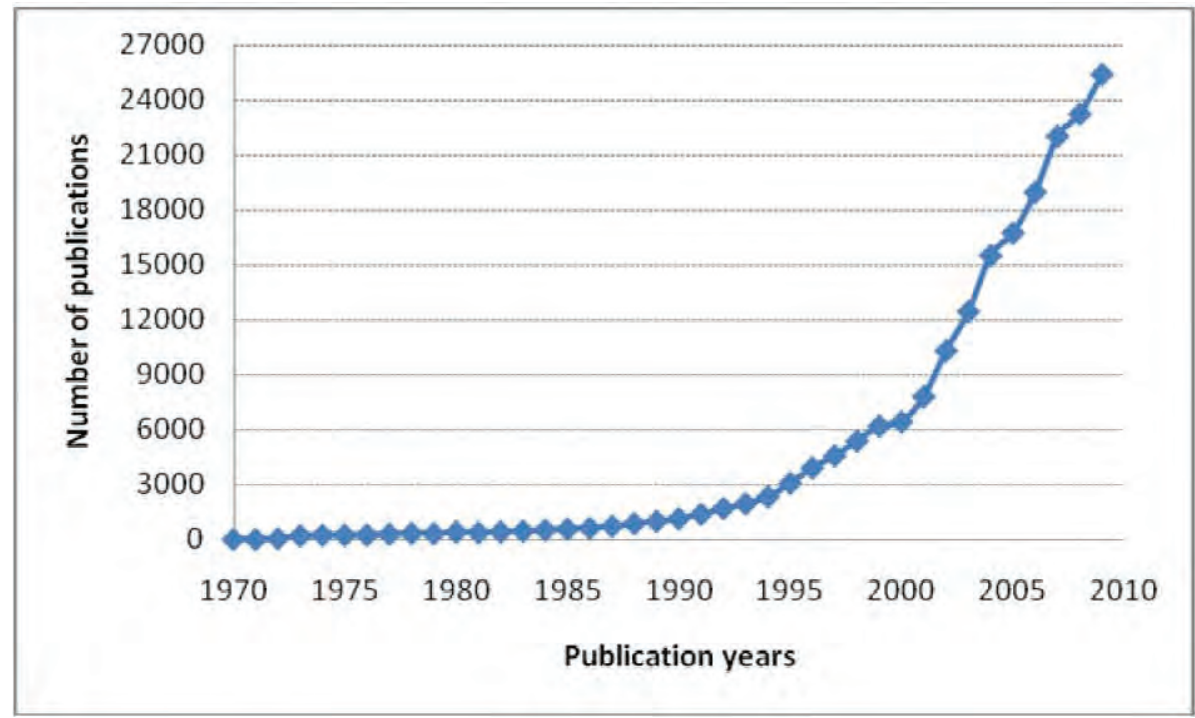

Figure 1

Number of Turkey addressed publications by year within the citation indexes $(N=198,595)$ 


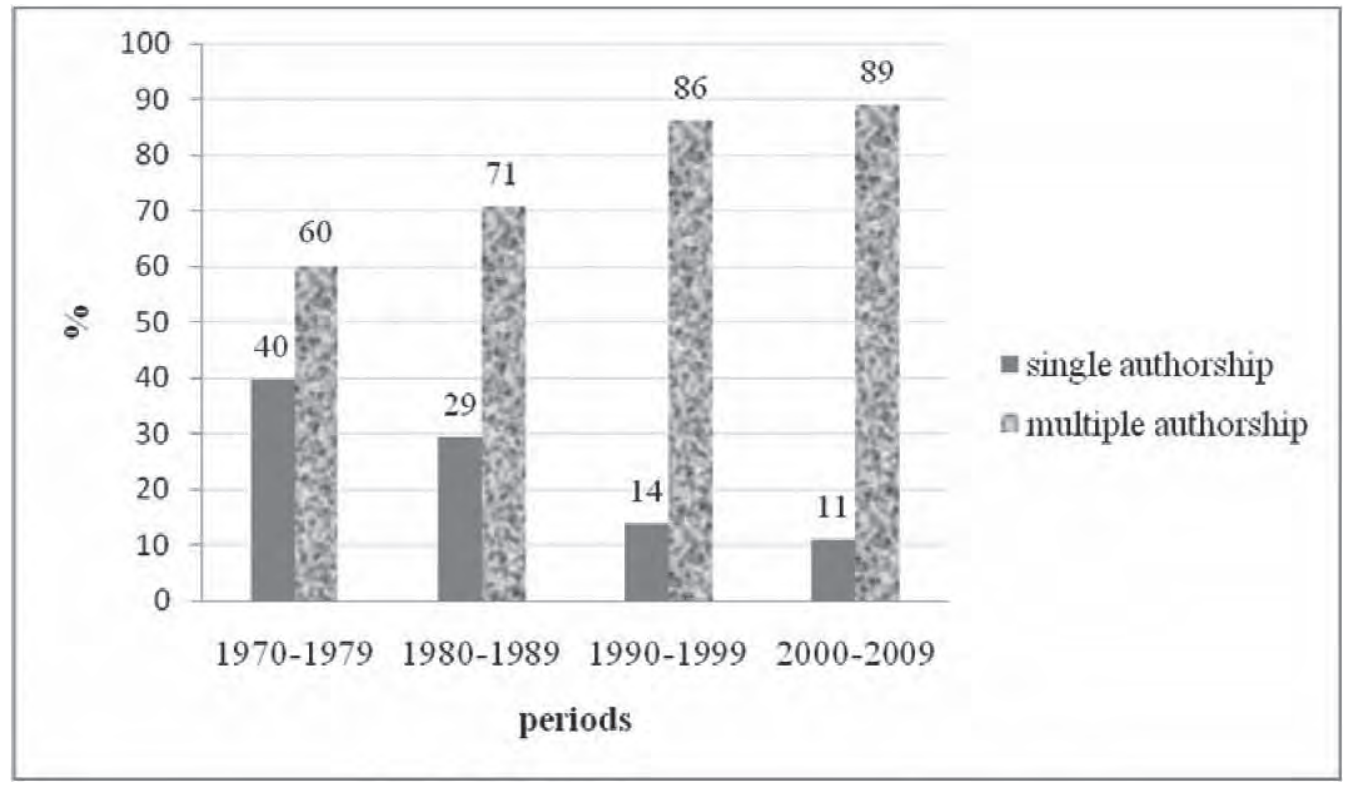

Figure 2

Distribution of publications by authorship

Table 1

Distribution of publications by authorship (2000-2009)

\begin{tabular}{cccccc}
\hline & \multicolumn{2}{c}{ Single } & \multicolumn{2}{c}{ Multiple } & \\
\cline { 2 - 4 } Year & $\mathrm{N}$ & $\%$ & $\mathrm{~N}$ & $\%$ & Total \\
\hline 2009 & 3,142 & 12.4 & 22,228 & 87.6 & 25,370 \\
2008 & 2,696 & 11.6 & 20,513 & 88.4 & 23,209 \\
2007 & 2,443 & 11.1 & 19,549 & 88.9 & 21,992 \\
2006 & 1,894 & 10.0 & 17,045 & 90.0 & 18,939 \\
2005 & 1,616 & 9.7 & 15,106 & 90.3 & 16,722 \\
2004 & 1,603 & 10.3 & 13,892 & 89.7 & 15,495 \\
2003 & 1,386 & 11.1 & 11,053 & 88.9 & 12,439 \\
2002 & 1,165 & 11.3 & 9,141 & 88.7 & 10,306 \\
2001 & 798 & 10.2 & 7,008 & 89.8 & 7,806 \\
2000 & 713 & 11.1 & 5,713 & 88.9 & 6,426 \\
\hline
\end{tabular}

\subsection{Collaboration types}

Although citation indexes have usually American and British based scientific publications, they still have an international character. The concept of internationality for citation indexes can be explained by the countries that contribute to or that benefit from the context 


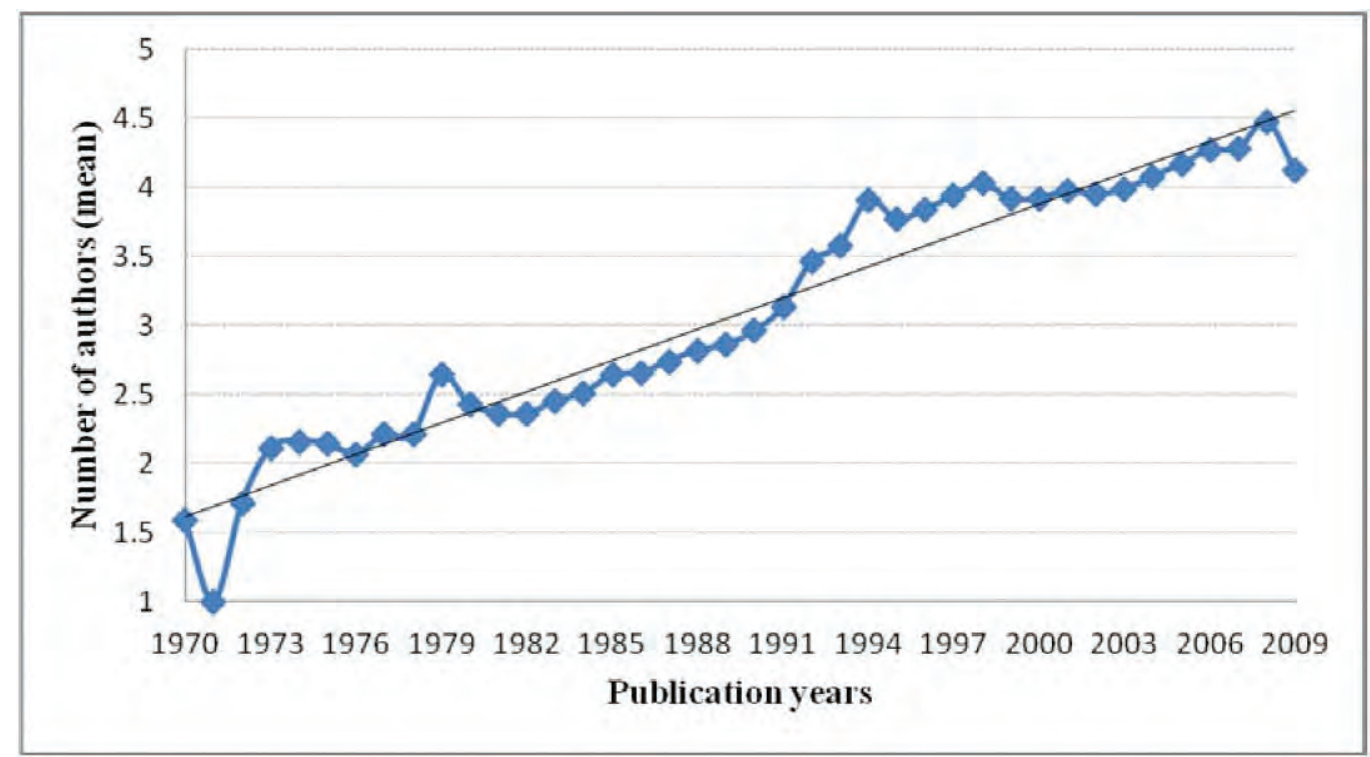

Figure 3

Average number of authors per publication

of citation indexes. However, when it comes to scientific publications, the language of the publication, contributions of researchers from different countries, the distribution of citations according to countries, can be counted as some of the indicators of internationality. From the bibliometric perspective, when compared to international publications, domestic publications known to have relatively low impact. In this study, to what extent was the production of publications carried out locally or internationally was investigated.

Within the scope of our study, the number of publications with multiple authorship was 174,145 , where 140,956 (80.9\%) of these publications were produced by the cooperation of Turkey addressed authors. The intensity of cooperation among the Turkey addressed authors indicates that Turkey addressed publications, at a certain point, have local features. Figure 4 reveals the increase of collaboration of Turkey addressed authors for the publications produced in Turkey over time. On the one hand, Turkey addressed journals that were recently included in the citation indexes increase the number of publications originated in Turkey, and it seems like they also inflated the local collaborative environment of Turkey addressed authors. It is a known fact that these journals usually include Turkey addressed researchers' publications and their language is generally Turkish ( $\mathrm{Al} \&$ Soydal, 2011, 13-29[2]).

\subsection{Collaboration in different disciplines}

We will also look into the collaboration patterns of Turkish scholars in different disciplines. It is important to understand the collaboration types in scholarly communication in order to derive a legitimate science policy in a country. 


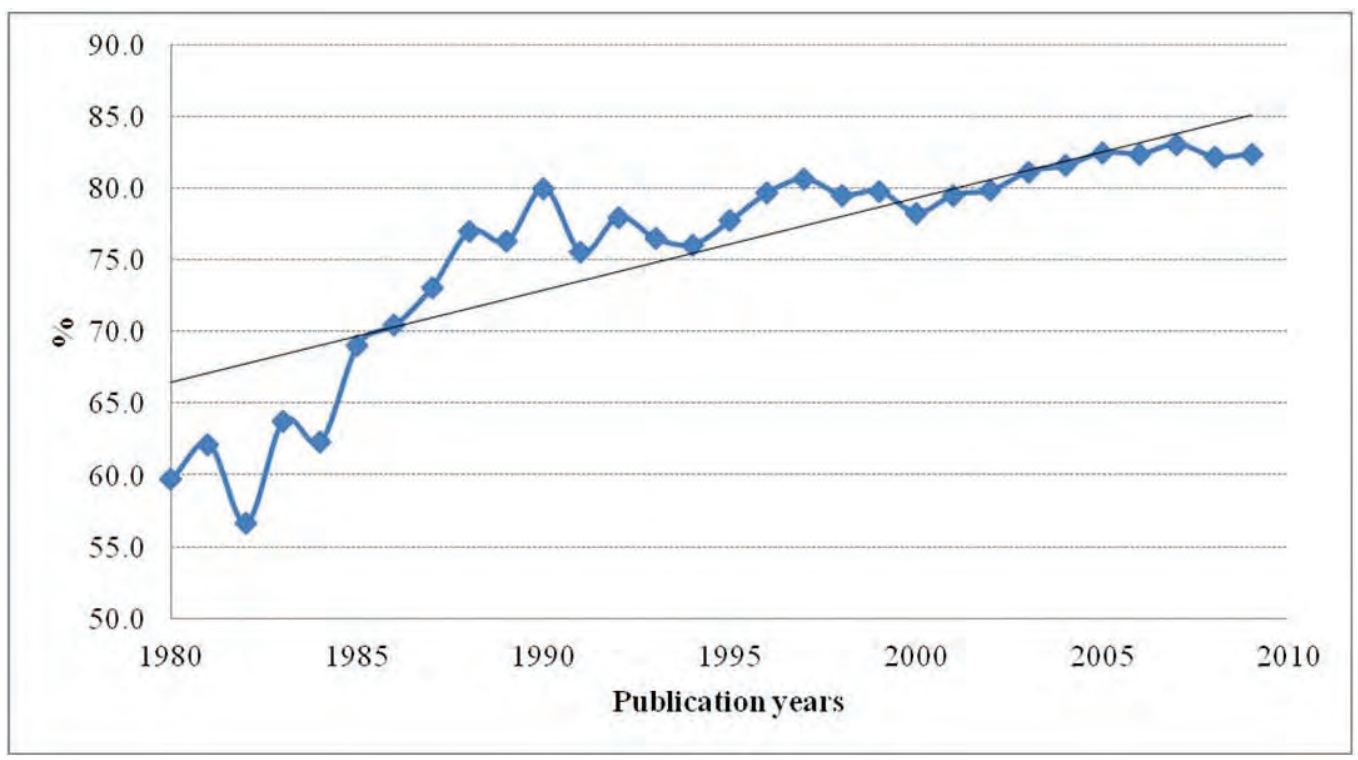

Figure 4

Percentage of Turkey's intranational publications by year (1980-2009)

Table 2

Authorship distribution by disciplines

\begin{tabular}{lrrrrr}
\hline & \multicolumn{2}{c}{ Single } & \multicolumn{2}{c}{ Multiple } & \\
\cline { 2 - 5 } Disciplines & $\mathrm{N}$ & $\%$ & $\mathrm{~N}$ & $\%$ & Total \\
\hline Surgery & 790 & 5.5 & 13,575 & 94.5 & 14,365 \\
Pediatrics & 550 & 6.0 & 8,592 & 94.0 & 9,142 \\
Clinical Neurology & 426 & 5.5 & 7,322 & 94.5 & 7,748 \\
Pharmacology \& Pharmacy & 356 & 4.8 & 7,048 & 95.2 & 7,404 \\
Cardiac \& Cardiovascular Systems & 246 & 4.0 & 5,873 & 96.0 & 6,119 \\
Engineering, Chemical & 1,006 & 16.7 & 5,021 & 83.3 & 6,027 \\
Environmental Sciences & 930 & 16.0 & 4,883 & 84.0 & 5,813 \\
Biochemistry \& Molecular Biology & 313 & 5.8 & 5,122 & 94.2 & 5,435 \\
Oncology & 213 & 4.0 & 5,137 & 96.0 & 5,350 \\
Radiology, Nuclear Medicine \& & & & & & \\
$\quad$ Medical Imaging & 329 & 6.2 & 4,999 & 93.8 & 5,328 \\
\hline
\end{tabular}

According to Thomson Reuters' classification, Turkey addressed researchers have made publications that belong to 247 different fields. Table 2 shows the top ten fields which Turkey had produced publications most frequently and the number of their authors. According to the table, the first five fields that have the greatest number of publications are 
Surgery (14,365), Pediatrics $(9,142)$, Clinical Neurology $(7,748)$, Pharmacology \& Pharmacy $(7,404)$ and Cardiac \& Cardiovascular Systems $(6,119)$. Multiple authorship tendency is dominant for the publications that were in the top five fields. However, the ratio of single authorship is higher for Engineering, Chemical and Environmental Sciences when compared with others. The highest multiple authorship ratio for Turkey addressed journals is for Genetics \& Heredity (98\%). The multi-disciplinary characteristic of this field and the quality of published works makes producing publications with single author almost impossible when it comes to accrediting the completed product.

Although multiple authorship predominates the most productive ones, there are still some differences among the whole fields. The evaluation of Turkey addressed publications on the basis of each field reveals that the publications of 41 fields (among the total of $247)$ have single author with a rate of $50 \%$ and above. Philosophy (98\%), Literature (97\%), Folklore (94\%), History (94\%), Religion (93\%) are among those fields. These ratios reflect the characteristics of researchers working in those fields and the working characteristics of the disciplines.

When examined by the disciplines, it is seen that Turkey addressed publications created in 210 different fields were conducted by an intranational collaboration with a ratio of $50 \%$. In this evaluation, it is also important to note that the number of fields with the publications written by multiple authors has decreased from 247 to 240 . On the other hand, for the fields that have publications written by internationally collaborated authors with a ratio of more than 50\% (30 fields), it should be considered that the total number of publications are relatively less than other fields. For example for the Law field, there are eight Turkey addressed publications and three of them have intranationally-collaborated authors where five of them have internationally-collaborated authors.

Table 3

Types of collaboration by disciplines

\begin{tabular}{lcrrrr}
\hline & \multicolumn{2}{c}{ Intranational } & \multicolumn{2}{c}{ International } & \\
\cline { 2 - 5 } Disciplines & $\mathrm{N}$ & $\%$ & $\mathrm{~N}$ & $\%$ & Total \\
\hline Surgery & 12,720 & 93.7 & 855 & 6.3 & 13,575 \\
Pediatrics & 8,120 & 94.5 & 472 & 5.5 & 8,592 \\
Clinical Neurology & 6,390 & 87.3 & 932 & 12.7 & 7,322 \\
Pharmacology \& Pharmacy & 5,849 & 83.0 & 1,199 & 17.0 & 7,048 \\
Cardiac \& Cardiovascular Systems & 5,464 & 93.0 & 409 & 7.0 & 5,873 \\
Engineering, Chemical & 4,428 & 86.2 & 709 & 13.8 & 5,021 \\
Environmental Sciences & 3,851 & 75.2 & 1,271 & 24.8 & 4,883 \\
Biochemistry \& Molecular Biology & 4,645 & 91.9 & 410 & 8.1 & 5,122 \\
Oncology & 4,127 & 82.2 & 894 & 17.8 & 5,137 \\
Radiology, Nuclear Medicine \& & & & & & \\
$\quad$ Medical Imaging & 4,502 & 90.1 & 497 & 9.9 & 4,999 \\
\hline
\end{tabular}


The collaboration in the most productive fields is shown in Table 3 and it is clearly seen that the number of publications that were created by international collaboration is significantly low. Even for Environmental Sciences field, which has the lowest ratio for intranational collaboration, every three of four publications have intranational structure. The intranational collaboration tendencies of Turkish researchers can be a problem in terms of international visibility.

\subsection{Collaborative partners of Turkey}

Researchers in Turkey have carried out joint studies with the researchers from 160 different countries. When the publications were evaluated entirely it can be seen that Turkey addressed researchers collaborated most frequently with the authors from United States of America, England, Germany, Italy, France, Canada, Japan, Netherlands, Switzerland and Spain respectively. It is a known fact that the USA has the highest number of scientific publications when compared to other countries. This is the main reason why the USA regarded as being well ahead among the countries that Turkey addressed researchers collaborated in the scientific publishing. In Table 4, the two other countries (England and Germany), ranking right after the USA, differ from the others in terms of the number of publications.

Figure 5 displays the international collaboration map of Turkey, where colour shading indicates the degree of collaboration with the darkest being the most collaborated. This figure shows that scientific collaboration of Turkey covers most of the world (160 different countries), while there are only a few countries (e.g., Angola, Papua New Guinea, Paraguay) residing in the white regions that Turkey does not have any collaboration with.

In this study, the ratio of articles within the whole publications was also investigated. It was found out that, the England has the highest (78.9\%) and Italy has the lowest (68.3\%) rate of publications among the 10 countries that Turkey has collaborated most frequently.

Table 4

The most collaborative countries with Turkey

\begin{tabular}{lccc}
\hline Countries & \# of publications & \# of articles & articles $(\%)$ \\
\hline USA & 13,911 & 10,610 & 76.3 \\
England & 4,298 & 3,392 & 78.9 \\
Germany & 3,997 & 3,011 & 75.3 \\
Italy & 2,176 & 1,486 & 68.3 \\
France & 2,141 & 1,555 & 75.6 \\
Canada & 1,531 & 1,168 & 76.3 \\
Japan & 1,415 & 1,082 & 76.5 \\
Netherlands & 1,290 & 928 & 71.9 \\
Switzerland & 1,045 & 732 & 70.0 \\
Spain & 985 & 697 & 70.8 \\
\hline
\end{tabular}




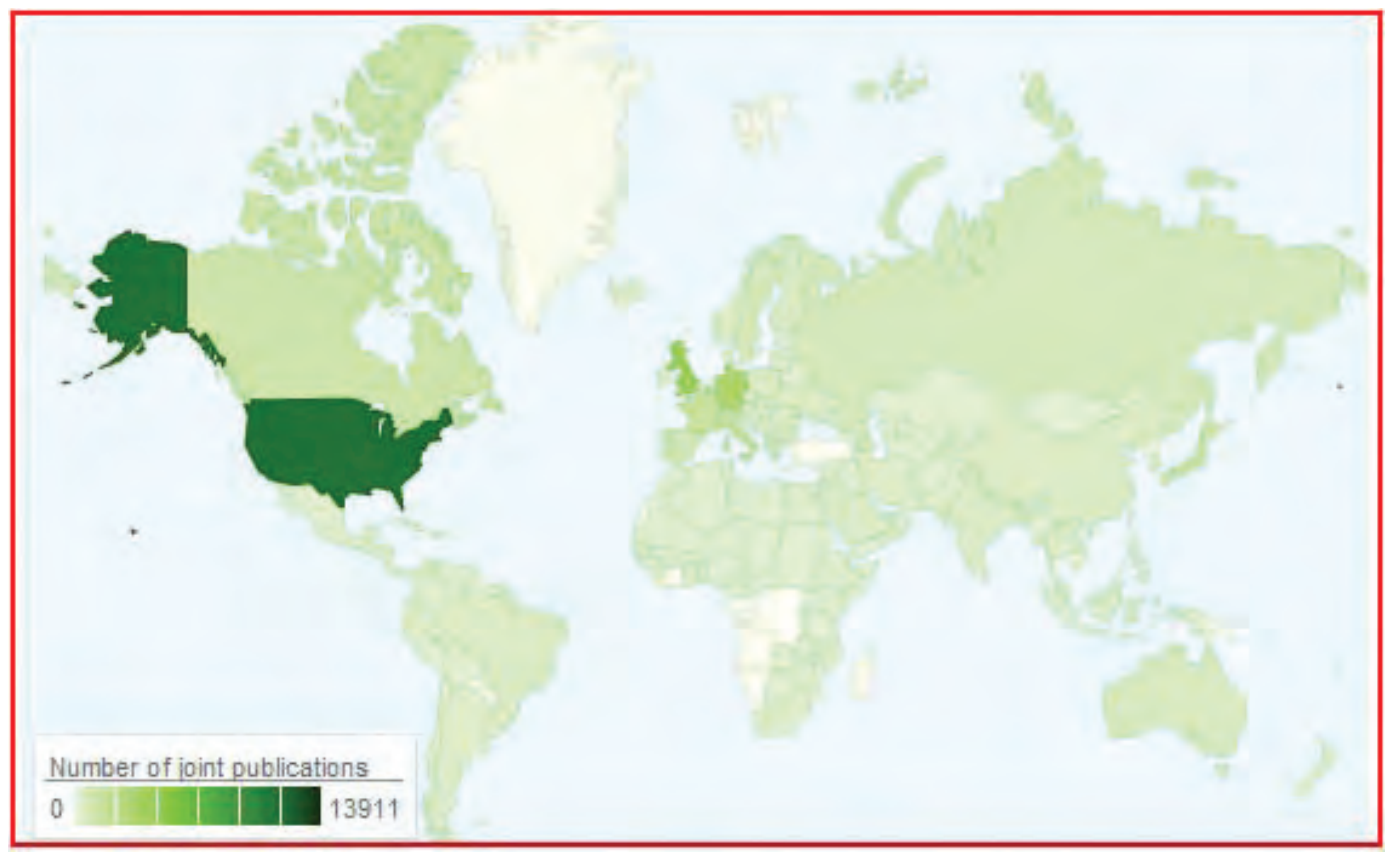

Figure 5

International collaboration map of Turkey

The reason why the People's Republic of China, Russia and Australia did not rank among the countries listed in Table 4, where frequently collaborated countries were listed, should be questioned, since they normally take place among (usually in the top 10) countries that has the highest number of publications. For instance, although People's Republic of China was the second most productive country in the world according to the data obtained from Essential Science Indicators [12], it ranked 23rd among the countries that Turkey has collaborated in terms of scientific publications. In our view, countries such as People's Republic of China and Russia were not fully able to keep pace with the globalized academic world.

Almost in all fields, the researchers that Turkey has collaborated most frequently were located in the USA. The countries that Turkey has collaborated most frequently other than the USA are Germany, England, Italy and France. It is observed that such countries as, Azerbaijan, Ukraine or Pakistan ranked unexpectedly top in some disciplines. For example, Azerbaijan is the fourth most frequently collaborated country of Turkey in Physics, Condensed Matter field. Similarly, in the Engineering, Electrical \& Electronic field, Ukraine is the fifth most frequently collaborated country of Turkey. To determine the countries and the fields that were being collaborated and its scientific consequences may have an impact on the preferences of the scientists for their future cooperation decisions. 
Table 5

The most collaborative countries with Turkey by disciplines (first five countries)

\begin{tabular}{|c|c|c|c|c|c|}
\hline Disciplines & $1(\mathrm{~N})$ & $2(\mathrm{~N})$ & $3(\mathrm{~N})$ & $4(\mathrm{~N})$ & $5(\mathrm{~N})$ \\
\hline Surgery & $\begin{array}{l}\text { USA } \\
(549)\end{array}$ & $\begin{array}{c}\text { Japan } \\
(68)\end{array}$ & $\begin{array}{l}\text { Germany } \\
(63)\end{array}$ & $\begin{array}{l}\text { Italy } \\
(41)\end{array}$ & $\begin{array}{l}\text { England } \\
(38)\end{array}$ \\
\hline Pediatrics & $\begin{array}{l}\text { USA } \\
(225)\end{array}$ & $\begin{array}{l}\text { Germany } \\
\quad(80)\end{array}$ & $\begin{array}{l}\text { England } \\
\quad(50)\end{array}$ & $\begin{array}{c}\text { France } \\
(44)\end{array}$ & $\begin{array}{l}\text { Italy } \\
(39)\end{array}$ \\
\hline Clinical Neurology & $\begin{array}{l}\text { USA } \\
(531)\end{array}$ & $\begin{array}{l}\text { Germany } \\
\text { (136) }\end{array}$ & $\begin{array}{l}\text { Italy } \\
(105)\end{array}$ & $\begin{array}{c}\text { England } \\
\text { (103) }\end{array}$ & $\begin{array}{c}\text { France } \\
(87)\end{array}$ \\
\hline Pharmacology \& Pharmacy & $\begin{array}{l}\text { USA } \\
(405)\end{array}$ & $\begin{array}{l}\text { Germany } \\
\text { (133) }\end{array}$ & $\begin{array}{c}\text { Japan } \\
(112)\end{array}$ & $\begin{array}{l}\text { England } \\
(109)\end{array}$ & $\begin{array}{c}\text { France } \\
(108)\end{array}$ \\
\hline $\begin{array}{l}\text { Cardiac \& Cardiovascular } \\
\text { Systems }\end{array}$ & $\begin{array}{l}\text { USA } \\
(184)\end{array}$ & $\begin{array}{c}\text { Russia } \\
(84)\end{array}$ & $\begin{array}{l}\text { Germany } \\
\text { (39) }\end{array}$ & $\begin{array}{l}\text { England } \\
\text { (39) }\end{array}$ & $\begin{array}{l}\text { Italy } \\
(32)\end{array}$ \\
\hline Engineering, Chemical & $\begin{array}{l}\text { USA } \\
(283)\end{array}$ & $\begin{array}{l}\text { England } \\
\text { (154) }\end{array}$ & $\begin{array}{l}\text { Germany } \\
\quad(90)\end{array}$ & $\begin{array}{l}\text { Japan } \\
(42)\end{array}$ & $\begin{array}{l}\text { Canada } \\
\text { (35) }\end{array}$ \\
\hline Environmental Sciences & $\begin{array}{l}\text { USA } \\
(283)\end{array}$ & $\begin{array}{l}\text { England } \\
\text { (154) }\end{array}$ & $\begin{array}{l}\text { Germany } \\
\quad(90)\end{array}$ & $\begin{array}{l}\text { Italy } \\
(41)\end{array}$ & $\begin{array}{l}\text { England } \\
\text { (38) }\end{array}$ \\
\hline $\begin{array}{l}\text { Biochemistry \& Molecular } \\
\text { Biology }\end{array}$ & $\begin{array}{l}\text { USA } \\
(495)\end{array}$ & $\begin{array}{l}\text { Germany } \\
\text { (161) }\end{array}$ & $\begin{array}{l}\text { England } \\
\text { (159) }\end{array}$ & $\begin{array}{l}\text { Italy } \\
\text { (95) }\end{array}$ & $\begin{array}{c}\text { France } \\
(89)\end{array}$ \\
\hline $\begin{array}{l}\text { Oncology } \\
\text { Radiology, Nuclear }\end{array}$ & $\begin{array}{l}\text { USA } \\
(384)\end{array}$ & $\begin{array}{l}\text { Italy } \\
(128)\end{array}$ & $\begin{array}{c}\text { France } \\
(108)\end{array}$ & $\begin{array}{l}\text { England } \\
\text { (97) }\end{array}$ & $\begin{array}{l}\text { Germany } \\
\text { (88) }\end{array}$ \\
\hline $\begin{array}{l}\text { Medicine \& Medical } \\
\text { Imaging }\end{array}$ & $\begin{array}{l}\text { USA } \\
(319)\end{array}$ & $\begin{array}{c}\text { France } \\
(58)\end{array}$ & $\begin{array}{l}\text { England } \\
\text { (56) }\end{array}$ & $\begin{array}{r}\text { Italy } \\
(48)\end{array}$ & $\begin{array}{l}\text { Germany } \\
\text { (43) }\end{array}$ \\
\hline
\end{tabular}

\section{Conclusion}

Today, it is observed that researchers from various fields contribute to the production of publications that has scope concerning multiple disciplines. The necessity for interdisciplinary researches and accordingly, the needs of researcher's from different disciplines for undertaking roles in collaborative studies play an important role in the growing number of publications written by multiple authors. These kinds of partnerships have an important impact on the development of science.

As a result of this study it could be said that the increasing trend of multiple authorship in the global scientific literature is also observed in the production of Turkey addressed publications. The study reveals that Turkey addressed publications were produced mostly with the collaboration of multiple authors which were generally limited in the country. Due to these reasons, most of the Turkey addressed scientific works could be counted as domestic publications. Having examined the scientific fields individually it was also observed that, in general, most of the fields also exhibit a tendency towards multiple authorship. 
In the scholarly communication process, multiple authorship not only helps scientists to think with different perspectives, but also could decrease the errors that could be arisen during the research and report phases which may be overlooked by one person. It is obvious that, to cooperate with specialists and research groups will be much easier with the globalization of the scientific world. This will improve the visibility and quality of the publications. It is also thought that, collaborations with both national and international researchers would especially help to the inexperienced researchers to increase their research abilities and to produce more qualified publications.

\section{Acknowledgments}

This study is supported by a research grant (no: 110K044) of the Turkish Scientific and Technological Research Center (TÜBİTAK).

\section{References}

[1] Al, U. Türkiye'nin bilimsel yayın politikası: Atıf dizinlerine dayah bibliyometrik bir yaklaşım. [Scientific publication policy of Turkey: A bibliometric approach based on citation indexes]. Unpublished Ph.D. dissertation. Hacettepe University, 2008.

[2] Al, U. \& Soydal, İ. Atıf dizinlerindeki Türkiye adresli dergiler üzerine bir değerlendirme. [An evaluation on Turkey addressed journals in citation]. Bilgi Dünyas1, Vol. 12(1), 2011, pp. 13-29.

[3] Anuradha, K. T. and Urs, S. R. Bibliometric indicators of Indian research collaboration patterns: A correspondence analysis. Scientometrics, Vol. 71(2), 2007, pp. 179-189.

[4] Arunachalam, S. International collaboration in science: The case of India and China. In B. Cronin and H.B. Atkins (Eds.), The Web of Knowledge: A festschrift in honor of Eugene Garfield, New Jersey: Information Today, 2000, pp. 215-231.

[5] Bennett, D. M. and Taylor, D. Unethical practices in authorship of scientific papers, Emergency Medicine, Vol. 15(3), 2003, pp. 263-270.

[6] Birnholtz, J. P. When do researchers collaborate? Toward a model of collaboration propensity. Journal of the American Society for Information Science and Technology, Vol. 58(14), 2007, pp. 2226-2239.

[7] Bordons, M. and Gómez, I. Collaboration networks in science. In B. Cronin and H. B. Atkins (Eds.), The Web of Knowledge: A festschrift in honor of Eugene Garfield. New Jersey: Information Today, 2000, pp. 197-213.

[8] Bozeman, B. and Corley, E. Scientists' collaboration strategies: implications for scientific and technical human capital. Research Policy, Vol. 33(4), 2004, pp. 599-616.

[9] Cronin, B. Hyperauthorship: A postmodern perversion or evidence of a structural shift in scholarly communication practices?, Journal of the American Society for Information Science $\mathcal{E}$ Technology, Vol. 52(7), (2001, pp. 558-569. 
[10] Drenth, J. P. H. Multiple authorship: The contribution of senior authors, Journal of the American Medical Association, Vol. 280(3), 1998, pp. 219-221.

[11] Drenth, J.P.H. (2001). Professors responsible for increasing in authorship. International Congress on Biomedical Peer Review and Scientific Publication. Retrieved, July 8, 2011 from http:/ / www.ama-assn.org/public/peer/prau.htm.

[12] Essential Science Indicators. Country/territory rankings in (all fields). Retrieved, July 8, 2011 from http:/ / esi.isiknowledge.com/rankdatapage.cgi. (2011)

[13] Farahat, H. Authorship patterns in agricultural sciences in Egypt, Scientometrics, Vol. 55(2), 2002, pp. 157-170.

[14] Glynn, R. W., Kerin, M. J., and Sweeney, K. J. Authorship trends in the surgical literature. British Journal of Surgery, Vol. 97, 2010, pp. 1304-1308.

[15] Hunter, L. and Leahey, E. Collaborative research in sociology: Trends and contributing factors. The American Sociologist, Vol. 39(4), 2008, pp. 290-306.

[16] Katz, J. S. Bibliometric assessment of intranational university-university collaboration. Unpublished Ph.D. dissertation. University of Sussex. Retrieved, July 8, 2011 from http: / / www.sussex.ac.uk/Users/sylvank/pubs/JSKatz-Thesis-1992.pdf. (1992)

[17] Katz, J. S. and Hicks D. How much is a collaboration worth? A calibrated bibliometric model. Scientometrics, Vol. 40(3), 1997, pp. 541-554.

[18] Katz, J. S. and Martin, B. R. What is research collaboration? Research Policy, Vol. 26(1), 2007, pp. 1-18.

[19] Kim, M. J. Korean science and international collaboration, 1995-2000. Scientometrics, Vol. 63(2), 2005, pp. 321-339.

[20] Kliegl, R. and Bates, D. . International collaboration in psychology is on the rise. Scientometrics, Vol. 87(1), 2011, pp. 149-158.

[21] Liu, Z. Trends in transforming scholarly communication and their implications, Information Processing \& Management, Vol. 39(6), 2003, pp. 889-898.

[22] Ma, N. \& Guan, J. An exploratory study on collaboration profiles of Chinese publications in Molecular Biology. Scientometrics, Vol. 65(3), 2005, pp. 343-355.

[23] Mussurakis, S. Coauthorship trends in the leading radiological journals, Acta Radiologica, Vol. 34(4), 1993, pp. 316-320.

[24] Perianes-Rodríguez, A., Olmeda-Gómez, C., Antonia Ovalle-Perandones, M.A., Chinchilla-Rodríguez, Z. \& Moya-Anegón, F. R\&D collaboration in 50 major Spanish companies. Aslib Proceedings, Vol. 63(1), 2011, pp. 5-27.

[25] Persson, O., Glänzel, W., and Danell, R. Inflationary bibliometrics values: The role of scientific collaboration and the need for relative indicators in evaluative studies. Scientometrics, Vol. 60(3), 2004, pp. 421-432.

[26] Sonnenwald, D. H. Scientific collaboration. Annual Review of Information Science and Technology, 41, 2007, pp. 643-681. 
[27] Sooryamoorthy, R. Do types of collaboration change citation? Collaboration and citation patterns of South African science publications. Scientometrics, Vol. 81(1), 2009, pp. 177-193.

[28] Wagner, C.S. and Leydesdorff, L. Network structure, self-organization, and the growth of international collaboration in science. Research Policy, Vol. 34(10), 2005, pp. 1608-1618.

[29] Yan, E., Ding, Y. and Zhu, Q. Mapping library and information science in China: A coauthorship network analysis. Scientometrics, Vol. 83(1), 2010, pp. 115-131.

[30] Zhao, Q. and Guan, J. International collaboration of three 'giants' with the G7 countries in emerging nanobiopharmaceuticals. Scientometrics, Vol. 87(1), 2011, pp. 159-170. 